\title{
Blasts 5-19 Percent of Bone Marrow Nucleated Cells
}

National Cancer Institute

\section{Source}

National Cancer Institute. Blasts 5-19 Percent of Bone Marrow Nucleated Cells. NCI

Thesaurus. Code C150455.

A semi-quantitative microscopic finding indicating that between 5 and 19 percent of the nucleated cells in a bone marrow sample are immature mononuclear cells. 